\title{
Associate Editor Diana Rubin
}

We would like to introduce our new associate editor.

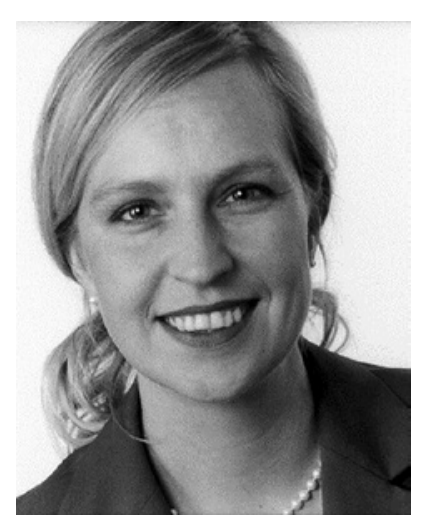

DRK Klinikum Berlin Mitte, Berlin, Germany and Associate Professor at Kiel Medical School, Christian Albrechts Universität zu Kiel, Germany
Diana Rubin is senior consultant of the Department for Gastroenterology at DRK Klinikum Mitte in Berlin/Germany and Associate Professor of Internal Medicine/Nutrition at Kiel Medical School/Germany. Diana has special interest in nutrition in hepatology and nephrology and a strong scientific record in nutrigenetics and gene nutrient interaction, mainly in the field of fasting and postprandial metabolism, lipidology and the metabolic syndrome. Diana is also experienced in the field of child nutrition/breastfeeding, as she was part of the national breastfeeding society and head of the unit for Nutritional Risks, Allergies and Novel Foods at the German Federal Institute for Risk Assessment.

She is in the board of German Society for Nutritional Medicine (DGEM) and the nutrition working group of German Diabetes Society. She is also a member of the European working group for hospital nutrition of the European Society for Clinical Nutrition and Metabolism. She is a board-certified gastroenterologist and diabetologist and has published over 30 peer-reviewed articles in the field of the metabolic syndrome and nutrigenetics.

\section{KARGER}

(c) 2018 S. Karger AG, Basel

E-Mail karger@karger.com

www.karger.com/anm
Dr. Diana Rubin

Vivantes, Netzwerk für Gesundheit GmbH

Aroser Allee 72-76

DE-13407 Berlin (Germany)

E-Mail d.rubin@drk-kliniken-berlin.de 